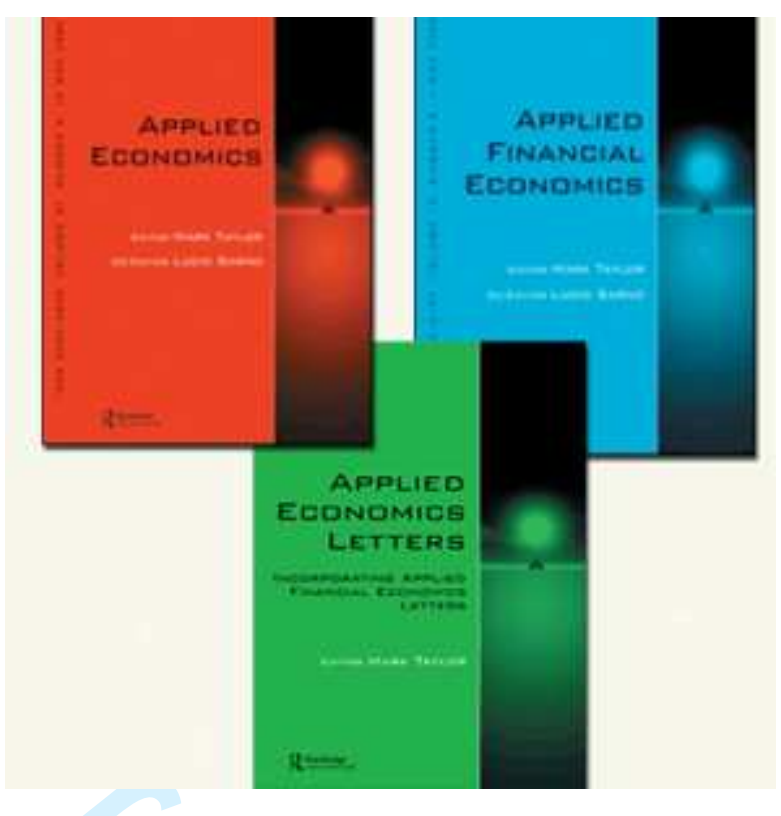

\title{
Industrial concentration and price-cost margin in the Indonesian food and beverages sector
}

\begin{tabular}{|r|l|}
\hline Journal: & Applied Economics \\
\hline Manuscript ID: & APE-2010-0235.R1 \\
\hline Journal Selection: & Applied Economics \\
\hline Author: & $29-$ Sep-2010 \\
\hline Complete List of Authors: & $\begin{array}{l}\text { Setiawan, Maman; Wageningen University, Business Economics } \\
\text { Group; University of Padjadjaran, Economics } \\
\text { Emvalomatis, Grigorios; Wageningen University, Business } \\
\text { Economics } \\
\text { Oude Lansink, Alfons; Wageningen University, Business Economics }\end{array}$ \\
\hline JEL Code: & $\begin{array}{l}\text { D43 - Oligopoly and Other Forms of Market Imperfection < D4 - } \\
\text { Market Structure and Pricing < D - Microeconomics, L16 - Industrial } \\
\text { Organization and Macroeconomics, Industrial Price Indices < L1 - } \\
\text { Market Structure, Firm Strategy, and Market Performance < L - } \\
\text { Industrial Organization, K21 - Antitrust Law < K2 - Regulation and } \\
\text { Business Law < K - Law and Economics, C33 - Models with Panel } \\
\text { Data < C3 - Econometric Methods: Multiple/Simultaneous Equation } \\
\text { Models < C - Mathematical and Quantitative Methods, L11 - } \\
\text { Production, Pricing, and Market Structure|Size Distribution of Firms } \\
\text { < L1 - Market Structure, Firm Strategy, and Market Performance < }\end{array}$ \\
\hline
\end{tabular}


Industrial Concentration, Price-Cost Margin, Food and Beverages Industry, Competition Law 


\section{Industrial concentration and price-cost margin of the Indonesian food and beverages sector}

Maman Setiawan $^{\mathrm{a}, *}$, Grigorios Emvalomatis ${ }^{\mathrm{b}}$, and Alfons Oude Lansink ${ }^{\mathrm{c}}$

\footnotetext{
${ }^{a}$ Business Economics, Wageningen University, Hollandseweg $16709 \mathrm{KN}$, Wageningen, the Netherlands and Faculty of Economics, University of Padjadjaran, Jl. Dipati Ukur 35 Bandung, Indonesia

${ }^{b}$ Business Economics, Wageningen University, Hollandseweg $16709 \mathrm{KN}$, Wageningen, the Netherlands

${ }^{c}$ Business Economics, Wageningen University, Hollandseweg 16709 KN, Wageningen, the Netherlands

*Corresponding author.Email : maman.setiawan@wur.nl
} 


\section{Abstract}

This paper investigates trends in industrial concentration and its relationship with the price-cost margin in 54 subsectors of the Indonesian food and beverages sector in the period 1995-2006. This study uses firmlevel survey data provided by the Indonesian Bureau of Central Statistics (BPS), classified at the fivedigit International Standard Industrial Classification (ISIC) Level. The results show a significant increase in industrial concentration in 1995 to 1999 , which coincided with the period of the economic crisis in Indonesia. After 1999, the industrial concentration exhibits a slightly decreasing long-term trend. Furthermore, the industrial concentration for all subsectors tends to converge to the same value in the long run. Additionally, results show that higher industrial concentration yields a higher price-cost margin. Finally, the introduction of the competition law in 1999 has slightly lowered industrial concentration and the price-cost margin.

Keywords: industrial concentration, price-cost margin, competition law, food and beverages sector

\section{Introduction}

It is well known that the industrial concentration in almost all of the economic sectors of Indonesia is relatively high (see Bird, 1999). Some sectors in the industry may have a stable and high industrial concentration because of the barriers to entry for new potential firms. The barriers may be caused by natural conditions, such as economies of scale moulded by incumbents, or formal regulations, such as exclusive monopolies, or business strategy.

One of the industry sectors with a high concentration is the food and beverages sector. Data presented by Bird (1999) showed that almost all of the subsectors of the food and beverages sector are highly concentrated. Furthermore, Bird concluded that for some of them, high concentration is particularly persistent.

The food and beverages sector contributes significantly to the Indonesian GDP. Since 2004, the output of this sector accounted for about $7 \%$ of the GDP and about $23 \%$ of the total industrial manufacturing output. This sector plays a vital role in the Indonesian economy and is a public concern, especially in fulfilling basic food needs. Furthermore, the total Indonesian population of about 206 million in 2000 indicates that this industry is an important sector. Additionally, the food and beverages sector absorbed about $23 \%$ of total employment in the Indonesian 
manufacturing industry in 2006, and employment in the industry grew significantly (about 19\%) in 2006 compared to 2005 .

Naturally, policy makers and researchers pay considerable attention to the relationship between the degree of competition and the price markup in the food and beverages sector, mainly because high industrial concentration in the sector will lead to the extraction of consumer surplus by the firms, with consequences for the entire population, but especially for lower income households. The higher industrial concentration may induce a few dominant firms with market power to behave collusively and to generate excess profits by keeping food prices higher than in a more competitive market.

In 1999, the Indonesian Competition Law No. 51999 was established. This law was designed to increase effectiveness and efficiency in economic activities through the creation of fair business competition and, subsequently, to improve the people's welfare. The Commission for the Supervision of Business Competition (KPPU) has been the body responsible for enforcing the law in Indonesia. Although the KPPU has limited the anti-competitive behavior of firms, the high concentration in the food and beverages sector continues to exist. Furthermore, a study investigating the competition law in Indonesia that was conducted after the competition law had been established (Pangestu, Aswicahyono, Anas, and Ardyanto, 2002) found ambiguities that are still subject to interpretation in the competition law. The ambiguities may make the investigation and the law enforcement on anti-competitive behavior ineffective.

Some previous studies, such as Hill (1987) and Bird (1999), focused on the industrial concentration before the Indonesian Competition Law was implemented. Hill (1987) and Bird (1999) observed the industrial manufacturing concentration in Indonesia and found that the seller concentration was remarkably high. Similar research about the trend of the industrial concentration in another Asian country, Malaysia, was conducted by Bhattacharya (2002). However, a thorough study of the trend of industrial concentration in the food and beverages sector has never been conducted in Indonesia.

As briefly explained in the structure-conduct-performance (SCP) paradigm, the firms in the concentrated industry will have a better industrial performance (usually measured by profitability or price-cost margin). Some research related to the relationship between the industrial concentration and the price-cost margin has been conducted, but mostly in the U.S. and some European countries (Collins and Preston, 1966; Sizrazi, 1974; Ghosal, 1989; and Prince and 
Thurik, 1992; Dickson, 2005). A few studies have focused on the relationship between industrial concentration and price markup in Asian countries. Gan (1978) and Kalirajan (1993), for example, observed that there was a positive and significant influence of industrial concentration on the price-cost margin in Malaysian manufacturing. Go, Kamerschen, and Delorme (1999) also found a positive relationship between the seller's concentration and the price-cost margin in Filipino manufacturing industries. Most of the research conducted to date investigated all subsectors of the manufacturing industry. Additionally, the research connecting the relationship between industrial concentration and the price-cost margin in the Indonesian food and beverages sector is hardly found in the published literature, nationally or internationally. The information about the relationship between the industrial concentration and the price-cost margin will provide further insight for the policy makers on whether the firms in the industry gain more producer surplus through the lessening of the competition and anti-competitive behavior in the industry. Therefore, the investigation of the effect of industrial concentration on industrial performance has a high relevance for policy makers.

The objectives of this paper are twofold. First, this paper analyzes the trend of industrial concentration in the Indonesian food and beverages sector in the period before and after the establishment of Indonesian Competition Law. The analysis of the trend includes a test for the convergence of industrial concentration in the long run. Second, this paper analyzes the relationship between industrial concentration and the price-cost margin in the Indonesian food and beverages industry. Additionally, the effect of the competition law establishment on the price-cost margin is measured.

\section{Industrial Concentration and the Price-Cost Margin}

Industrial concentration is a common measure of market structure ${ }^{1}$. It reflects both the number and size distribution of firms in an industry. The industrial concentration may represent the market power and the probability of anti-competitive behavior among firms in the market.

The most commonly used measures of industrial concentration are the concentration ratio for n firms $\left(C R_{n}\right)$ and the Herfindahl-Hirshman Index (HHI), which is based on Pepall et al. (2008).

\footnotetext{
${ }^{1}$ We define industrial concentration as in Bain (1951)
} 
Both indicators of industrial concentration are based on the market share of the firms and calculated by the following formulas: ${ }^{2}$

$$
\begin{aligned}
& \mathrm{CR}_{\mathrm{j}}=\sum_{\mathrm{i}=1}^{4} \mathrm{MS}_{\mathrm{i}} \\
& \mathrm{HHI}_{\mathrm{j}}=\sum_{\mathrm{i}=1}^{\mathrm{n}}\left(\mathrm{MS}_{\mathrm{i}}\right)^{2}
\end{aligned}
$$

where $j=1,2, \ldots, m$ indexes the subsector, $i=1,2, \ldots n$ indexes firm $i$ in a subsector, and $M S_{i}$ is the market share of firm $i$ in its respective subsector. CR4 considers the collective share of the four largest firms in a subsector, while $H H I_{j}$ considers the inequality of distribution of market shares among all firms in subsector $j$.

Both the CR4 and the Herfindahl-Hirschman Index (HHI) measures have a limitation in the calculation, but they complement each other. ${ }^{3}$ Hence, it is necessary to use both concentration measures to clearly picture the market structure in the industry.

Additionally, there are some shortcomings related to the calculation of the concentration ratio (CR4 and HHI). The calculation of the concentration ratio will underestimate or overestimate the "true concentration" for a series of reasons (Bird, 1999). First, the survey of industrial manufacturing in Indonesia includes only the firms classified into large and medium firms. ${ }^{4}$ This may overestimate the industrial concentration because small firms are not reported in the survey. Second, BPS reports firm data based on establishment. The industrial concentration may be underestimated because the calculation may include leading firms that have more than one establishment. Third, the unavailability of information on merger activity in the data, especially about horizontal mergers, is likely to lead to an underestimation of the industrial concentration. Fourth, because the industrial concentration may be higher in the regional than in the national level, the calculation of industrial concentration in the national level will be underestimated.

\footnotetext{
${ }^{2}$ Considering stocks, this paper calculates industrial concentration based on sales data because sales seem to explain more about the market share than the output.

${ }^{3}$ CR4 is commonly used to classify the market into some categories of oligopoly (see Shepherd, 1999), but it cannot capture the distribution of the market share for all firms in the market. However, HHI can capture the distribution of the a firm's market share in a market, but it is rather difficult to classify the oligopoly categories from the HHI. In spite of this, Besanko (2004) gave a classification of market structure based on HHI. Furthermore, Liebenberg and Kamerschen (2008) also discusses the importance of using both HHI and concentration ratio.

${ }^{4}$ BPS defines medium-sized firms as those firms employing more than 20 workers.
} 
Finally, it is noted that the industries examined may not be "markets" (see Kamerschen, 1994 for details).

The degree of the biases induced for the reasons mentioned above may not be substantial. Bird (1999) gives some arguments in this regard. First, Hill (1990) argued that, in the aggregate, the exclusion of small firms is not a serious problem because small firms contribute no more than $15 \%$ of the total manufacturing value added in 1985. Second, different results may exist in the industrial concentration calculation between the method that uses the calculation from BPS establishment data and the one that uses the primary firm data. Although there will be differences, the industrial concentration trend may still be captured quite accurately. Third, vertical, rather than horizontal mergers, are more frequent in Indonesian economy. Therefore, the unavailability of information on merger activity will not have a great impact on the industrial concentration calculation. Finally, all factors underestimating or overestimating the concentration appear not to undermine the trend of the concentration, if their net effects remain constant over time (Bird, 1999).

This paper also estimates the effect of industrial concentration on industrial performance measured by the price-cost margin. The relationship arises because higher industrial concentration may lead to higher industrial performance (Bain, 1951; Gupta, 1983). A mathematical derivation of the effect of industrial concentration on the price-cost margin can be found in Saving (1970), Cowling and Waterson (1976), Fischer and Kamerschen (2003a, 2003b), and Kamerschen, Klein, and Porter (2005).

Industrial performance is measured by price-cost margin (Sizrazi, 1974; Domowitz, Hubbard, and Petersen, 1986; Prince and Thurik, 1992). The price-cost margin (PCM) is calculated according to the formula proposed by Domowitz, Hubbard, and Petersen ${ }^{5}$ (1986) and Prince and Thurik (1992). This formula allows for changes in inventories ( $\Delta$ Inventories), considering that changes in inventories are important with regard to the fluctuation in the business cycle in the Indonesian economy from 1995-2006:

\footnotetext{
${ }^{5}$ Their (1988) article which has a connection to this article has been challenged by Kamerschen and Park (1993a, 1993b). In the same year, Domowitz, Hubbard, and Petersen (1993) replied that they did not view the Comment by Kamerschen and Park (1993a, 1993b) as a substantive criticism of their (1988) paper, and the issue remains open.
} 
$\mathrm{PCM}=\frac{\text { Value Added }- \text { Cost of Labor }+\Delta \text { Inventories }}{\text { Sales }+\Delta \text { Inventories }}$

Value added is calculated by sales minus intermediate inputs except labor cost.

\section{Data}

The CR4 and HHI for the food and beverages industry are calculated using firm-level data from the Annual Manufacturing Survey provided by the Indonesian Bureau of Central Statistics (BPS). The dataset covers the period from 1995 to 2006. This paper uses that period because of the tractable and comparable data for all subsectors among the years. Furthermore, data beyond 2007 have not yet been published.

There are 59 subsectors of International Standard Industrial Classification (ISIC) Level $^{6}$ in the food and beverages industry, 55 of which are related to food processing, with the remaining to the beverages industry. This paper excludes five subsectors from the analysis because they contain less than four firms in each period. Therefore, this paper uses only 54 of the subsectors in the industry. During the period covered by the data, there were, on average, 5488 firms in the market. About 7.6 percent of them, on average, were involved in exporting activities. In 1995 the food and beverages sector had 5335 firms. This number increased significantly to 7897 in 2006. Despite this, the number of firms had decreased significantly from 5495 to 4850 (a drop of 12\%) in 1998, the year that coincided with a major economic crisis in Indonesia.

Table 1. Descriptive statistics of the variables from 1995-2006

\begin{tabular}{lrrrrr}
\hline \multicolumn{1}{c}{ Variable } & Mean & \multicolumn{1}{c}{$\begin{array}{c}\text { Standard } \\
\text { Deviation }\end{array}$} & $\begin{array}{c}\text { Coefficient of } \\
\text { Variation }\end{array}$ & Minimum & Maximum \\
\hline CR4 & 0.633 & 0.274 & 0.433 & 0.081 & 1.000 \\
HHI & 2,266 & 2,143 & 0.946 & 51.5 & 10,000 \\
PCM & 0.181 & 0.126 & 0.696 & -0.380 & 0.708 \\
Size (Log of VA) & 13.700 & 2.227 & 0.162 & 5.552 & 18.498
\end{tabular}

\footnotetext{
${ }^{6}$ Actual codes used are not the ISIC codes, but comparable, coming from Klasifikasi Baku Lapangan Usaha Indonesia (KBLI)
} 


\begin{tabular}{lrrrrr}
\hline Variable & Mean & \multicolumn{1}{c}{$\begin{array}{c}\text { Standard } \\
\text { Deviation }\end{array}$} & $\begin{array}{c}\text { Coefficient of } \\
\text { Variation }\end{array}$ & Minimum & Maximum \\
\hline Growth & 0.453 & 1.319 & 2.912 & -0.942 & 6.963 \\
COR & 0.018 & 0.161 & 8.944 & $5.27 .10^{-6}$ & 3.937 \\
N-Subsectors & 54 & 54 & 54 & 54 & 54 \\
& & & & & \\
\hline
\end{tabular}

Table 1 shows that the data are relatively heterogeneous, with relatively high standard deviations and coefficients of variation for all variables. In the period covered by the data, it is observed that the average of CR4 is 0.6328 , which characterizes the food and beverages sector as a tight oligopoly, according to the criteria of Shepherd (1999). It is also seen that the average HHI is 2,266, which according to Besanko (2004), this classifies the food and beverages sector as an oligopoly. The average PCM of 0.181 also indicates that the firms in the sector have a positive price markup. Regarding all variables, the data on demand growth (Growth) and capital output ratio (COR) are very heterogeneous. ${ }^{7}$ The heterogeneous condition of the demand growth and capital output ratio are related to the economic condition and capital-output applied by the firms, respectively. ${ }^{8}$

\section{Empirical Model and Estimation}

This paper uses two econometric models to investigate the trend of industrial concentration and the relationship between industrial concentration and the price-cost margin. The first model examines the trend of industrial concentration in the industry. It measures whether there is a trend for the industrial concentration to move to a certain value. To confirm the movement of the trend of industrial concentration for all subsectors in the food and beverages sector, this paper

\footnotetext{
${ }^{7}$ Although the data on demand growth and capital output ratio are too heterogeneous, this may not undermine the accuracy of the estimation given that these two variables appear only as instruments in the model.

${ }^{8}$ The lowest demand growth is found on subsector 15316 (Nuts), which dropped about $-94.21 \%$ in 2002 compared to 2001. According to the data survey, this may be caused by firms exiting the market, as well as the decrease in the demand for this product in 2002. The highest demand growth was experienced by subsector 15134 (Dried Fruit and Vegetables), which increased about 696\% in 1998 compared to 1997. The significant increase of the demand growth in 1998 is caused by the considerable increase of sales in 1998, after the sales drop caused by the crisis, starting in mid-1997. The high variation of the capital output ratio seems obvious because of the different capital used in each subsector. The subsector with the highest capital output ratio is 15143 (coconut oil), with a value of 3.937, whereas the subsector with the lowest capital output ratio is 15510 (liquors), with capital a output ratio of $5.27 * 10^{-6}$.
} 
uses the theory of absolute convergence ${ }^{9}$ (Barro and Sala-i-Martin, 1992; Sala-i-Martin, 1996; Sorensen and Whitta-Jacobsen, 2005). The model can indicate whether there is a tendency for the convergence of the industrial concentration in the long run to one and the same point for all subsectors. In other words, the model assumes that all subsectors have the same steady state in the long run. The assumption is relevant because all subsectors face the same business characteristics in the Indonesian economy. The absolute convergence model ${ }^{10}$ is defined as:

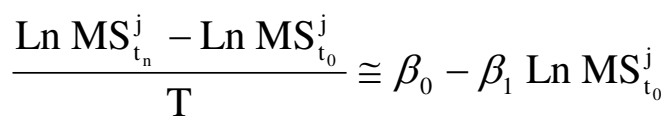

where $j=1,2, \ldots, 54$ indexes subsector, $\mathrm{t}_{0}$ is the initial year for which data are available (1995), and $t_{n}$ is the final year (2006). $M S_{t}^{j}$ is the market structure in period $t$ and subsector $\mathrm{j}$, captured by the CR4 and HHI. The model is estimated using cross section regression. The food and beverages sector exhibits convergence in market structure if the estimated coefficient of $\beta_{1}$ is significantly positive.

The second model estimates the effect of industrial concentration on the price-cost margin in the industry. Higher industrial concentration, followed by higher market power, increases the ability of the firms or an industry to influence the market equilibrium price. Thus, higher concentration is expected to lead to higher price-cost margins. Moreover, based on Konings et al. (2001), McCloughan et al. (2007), and Looi Kee and Hoekman (2003), the effect of the competition law on the price-cost margin is also investigated. The competition law is represented by the dummy variable of the competition law establishment in Indonesia as used by Looi Kee and Hoekman (2003). This paper also interacts the competition law dummy variable with the industrial concentration. This interaction variable can capture in the way industrial concentration affects the price-cost margin after the competition law establishment. The effect of the industrial concentration on the price cost margin may be lower after the establishment of the competition law because the law can break the cartel and other anti-competitive behavior. As a result, the competition law is also hypothesized to affect the price-cost margin indirectly through its influence on the industrial concentration. In addition, this paper also introduces trend variables and their interaction with the competition law dummy variable to see the trend of the price-cost

\footnotetext{
${ }^{9}$ This model is different from the model used by Bird (1999), who also investigated the trend of the industrial concentration using the models of Khemani (1980) and Brozen (1982).

${ }^{10}$ Derivation of this model can be found in Barro and Sala-i-Martin (1992) and Sala-i-Martin (1996).
} 
margin in the whole period as well as the competition law effect on the trend of the price cost margin. The final model of the industrial performance-concentration model ${ }^{11}$ is:

$\mathrm{PCM}_{\mathrm{jt}}=\gamma_{\mathrm{i}}+\theta_{1} \mathrm{MS}_{\mathrm{jt}}+\theta_{2} \mathrm{Law}_{\mathrm{t}}+\theta_{3} \mathrm{Law}_{\mathrm{t}} * \mathrm{MS}_{\mathrm{jt}}+\theta_{4} \operatorname{Trend}_{\mathrm{t}}+\theta_{5} \operatorname{Trend}_{\mathrm{t}} * \mathrm{Law}_{\mathrm{t}}+\mathrm{v}_{\mathrm{it}}$

where $\mathrm{j}$ and $\mathrm{t}$ index subsector and time, respectively. Law is a dummy variable that assumes the value 1 for the years after the establishment of the competition law (1999), Trend $=0,1,2, \ldots, T$, and PCM is the price-cost margin.

Regarding the relationship between industrial concentration and the price-cost margin, there is an endogeneity problem in the variable of industrial concentration (Clarke and Davis, 1982; Kalirajan, 1993). This endogeneity may arise because of the argument that the derivation of the price-cost margin comes from an equilibrium condition for profit maximization (Jacquemin et al., 1980; Kalirajan, 1993). Additionally, Clarke and Davis (1982) established the endogeneity problem through underlying cost and demand conditions. Therefore, this paper uses some instrumental variables for the industrial concentration. The instrumental variables chosen are based on the works of Muller and Ham (1974), Sizrazi (1974), Gupta (1983), Prince and Turik (1992), Kalirajan (1993), Go, Kamerschen, and Delorme (1999), and Delorme, Kamerschen, Klein, and Voeks (2002). The main instrumental variables estimating the industrial concentration are industry size (Size), growth of demand (Growth), and capital output ratio (COR). Besides the three main instrumental variables, this paper also uses a competition law dummy variable and trend variables as exogenous in the equation that determines PCM.

Equation (5) is estimated using unbalanced panel data techniques. ${ }^{12}$ This method uses either a fixed effects or random effects model based on the Hausman test (1978). The fixed-effects model is chosen if the Hausman test shows that there is correlation between individual effects and other regressors. Otherwise, the random effects model will be used. In addition, the fixed-effects model uses dummy variables of the subsectors as the source of the heterogeneity, whereas the random effects model uses the intercept deviation of each subsector across the intercept for all subsectors.

\footnotetext{
${ }^{11}$ The derivation of the relationship between industrial concentration and price-cost margin can be found in Cowling and Waterson (1976) and Clarke and Davis (1982).

${ }^{12}$ Some subsectors, such as 15145 and 15149, are not reported in 2006.
} 


\section{Results}

\subsection{Trends of Average Industrial Concentration}

Table 2 describes the industrial characteristics such as concentration for the CR4 (4 firms), the Herfindahl-Hirschman Index (HHI), the distribution of the number of firms, and the average price-cost margin. The table shows that the industrial concentration was high from 1995 to 2006, but there was a slightly declining trend, especially after the year 2000. This finding suggests that industrial concentration increased steadily before the establishment of Indonesian Competition Law No. 5 1999. After the establishment of the law, the industrial concentration decreased slightly over time. Furthermore, the CR4 and HHI decreased on average by $0.7 \%$ and $0.8 \%$, respectively, every year from 1995-2006. The average increasing number of the firms in the industry every year may also be the reason for which the concentration is decreasing.

The price-cost margin is always positive and exhibits a significant increase by on average 100.47\% from 1995-1999, which coincided with hyperinflation in 1997-1998 (firms sold the old stock at a new price) and the increase in the industrial concentration. The increase in the average industrial concentration from 1995-1999 may also have been caused by firms exiting the industry, especially from 1997-1999 because of the economic crisis. From 1998-1999 there was a $12 \%$ reduction in the number of firms in the industry. The reduction in the growth of the pricecost margin occurred simultaneously with the decline of the growth of the concentration from 2000-2006.

Table 2. Industrial characteristics 1995-2006

\begin{tabular}{lrrrr}
\hline \multicolumn{1}{c}{ Year } & \multicolumn{1}{l}{ CR4 } & HHI & Number of Firms & Average PCM \\
& & & & \\
\hline $1995-1997$ & 0.645 & 2572 & 5495 & 0.069 \\
$1998-2000$ & 0.713 & 3142 & 4850 & 0.225 \\
$2001-2003$ & 0.650 & 2381 & 5299 & 0.197 \\
2004-2006 & 0.626 & 2345 & 6308 & 0.235 \\
Average \% Change & -0.693 & -0.796 & 5.133 & 38.593 \\
1995-2006 & & & & \\
Average \% Change & 3.442 & 8.019 & -5.982 & 100.470 \\
1995-1999 & & -5.833 & 11.485 & 3.234 \\
Average \% Change & -3.056 & & & \\
2000-2006 & & &
\end{tabular}

Based on the estimation of Eq. 4, Table 3 shows that the parameter estimate for the initial industrial concentration is negative (implying that $\beta_{1}>0$ ), which means that there is absolute 
convergence in the industrial concentration in the long run. Therefore, in the long run, industrial concentration tends to converge to one and the same value for all subsectors. It can be concluded that the subsectors with a relatively low industrial concentration in 1995 grew relatively fast after the year 1995.

Table 3. Absolute convergence of industrial concentration

\begin{tabular}{|c|c|c|}
\hline \multirow[t]{3}{*}{ Independent Variable } & $\begin{array}{c}\text { Dependent Variable: } \\
\text { Ln CR } 4_{2006}^{\mathrm{j}}-\mathrm{Ln} \mathrm{CR} 4_{1995}^{\mathrm{j}} \\
\end{array}$ & $\begin{array}{c}\text { Dependent Variable: } \\
\text { Ln HHI }_{2006}^{\mathrm{j}}-\mathrm{Ln} \mathrm{HHI}_{1995}^{\mathrm{j}} \\
\end{array}$ \\
\hline & $\mathrm{T}$ & $\mathrm{T}$ \\
\hline & Coefficients & Coefficients \\
\hline Intercept & $\begin{array}{c}-0.025 * * * \\
(0.008)\end{array}$ & $\begin{array}{c}0.270 * * * \\
(0.073)\end{array}$ \\
\hline $\operatorname{LnCR}_{\mathrm{j}, 1995}\left(-\beta_{1}\right)$ & $\begin{array}{c}-0.029 * * * \\
(0.007)\end{array}$ & \\
\hline $\operatorname{LnHHI}_{\mathrm{j}, 1995}\left(-\beta_{1}\right)$ & & $\begin{array}{c}-0.039 * * * \\
(0.010)\end{array}$ \\
\hline $\mathrm{R}^{2}$ & 0.231 & 0.222 \\
\hline F-statistics & $15.606 * * *$ & $14.806 * * *$ \\
\hline
\end{tabular}

Table 4. Average \% change of industrial concentration (CR4)

\begin{tabular}{lclc}
\hline $\begin{array}{l}\text { The Five Largest } \\
\text { Industrial } \\
\text { Concentrations }\end{array}$ & $\begin{array}{l}\text { Average \% } \\
\text { Change }\end{array}$ & $\begin{array}{l}\text { The Five Lowest Industrial } \\
\text { Concentrations }\end{array}$ & $\begin{array}{l}\text { Average \% } \\
\text { Change }\end{array}$ \\
\hline $\begin{array}{l}15212 \\
\text { (Milk Food) }\end{array}$ & -1.015 & $\begin{array}{l}15492 \\
\text { (Ice Cubes, other ices) }\end{array}$ & 6.73 \\
$\begin{array}{l}15530 \\
\text { (Beer) }\end{array}$ & 0.055 & $\begin{array}{l}15311 \\
\text { (Rice Milling) }\end{array}$ & 19.41 \\
$\begin{array}{l}15321 \\
\text { (Wheat Flour) }\end{array}$ & -1.827 & $\begin{array}{l}15141 \\
\text { (Crude Cooking Oil) }\end{array}$ & 17.64 \\
$\begin{array}{l}15131 \\
\text { (Canned Fruit, Vegetables) }\end{array}$ & 1.043 & $\begin{array}{l}\text { 15496 } \\
\text { (Crackers and Other Chips) }\end{array}$ & 17.08 \\
$\begin{array}{l}15329 \\
\text { (Other Starch Nec) }\end{array}$ & 1.401 & $\begin{array}{l}\text { 15323 } \\
\text { (Tapioca) }\end{array}$ & 1.17 \\
\hline
\end{tabular}

Table 4 also supports this finding. It shows that the five most concentrated industries (according to CR4) tend to change slowly over times and some of them experienced concentration reduction, such as the milk, food and wheat flour subsectors. The five least concentrated (CR4) subsectors experienced a significant increase in concentration. For three of them, the increase was larger than $15 \%$, on average. 


\subsection{The Effect of Industrial Concentration on Price-Cost Margin}

Table 5 shows the results of the estimation of Equation (5), which is estimated using a fixedeffects model with stationary level-form data. The fixed-effects model is used because the Hausman test (1978) rejected the random effects specification. Furthermore, based on the stationarity test of Levin, Lin, Chu (LLC) test (2002), the null hypothesis of non-stationary data of the CR4 and PCM is rejected at the $1 \%$ critical level, which indicates that the data at the level form are valid for use in the model.

The White test for heteroscedasticity (Castilla, 2008) rejects the null hypothesis of the absence of heteroscedasticity at the $1 \%$ critical level. To address the problem of heteroscedasticity, this paper applies the generalized least square (GLS) method to estimate the model.

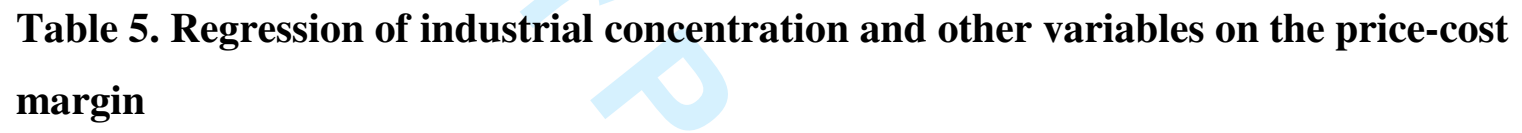

\begin{tabular}{lcc}
\hline Independent & \multicolumn{2}{c}{ Dependent Variable : AVERAGE PCM } \\
Variable & Coefficients & Coefficients \\
\cline { 2 - 3 } Intercept & $-0.499 * * *$ & $-0.189 * * *$ \\
CR4 & $(0.110)$ & $(0.043)$ \\
HHI & $0.824 * * *$ & \\
& $(0.196)$ & $0.091 * * *$ \\
Law & & $(0.025)$ \\
& & $0.339 * * *$ \\
Law ${ }^{*}$ CR4 & $0.373 * * *$ & $(0.033)$ \\
Law*HHI & $(0.043)$ & \\
Trend & $-0.342 * * *$ & -0.064 \\
& $(0.088)$ & $(0.019)$ \\
Trend*Law & & $0.049 * * *$ \\
$\mathrm{R}^{2}$ & $0.036 * * *$ & $(0.011)$ \\
F-statistics & $(0.012)$ & $-0.049 * * *$ \\
\hline
\end{tabular}

Notes: $*$ denotes test statistic significance at the $10 \%$ level ** denotes test statistic significance at the $10 \%$ level *** denotes test statistic significance at the $10 \%$ level Standard error in the parentheses 
The results in Table 5 suggest that industrial concentration has a significant effect on the price-cost margin, both for the CR4 and HHI measures. As expected, higher industrial concentration yields a higher price-cost margin for the firms. The CR4 coefficient of 0.824 indicates that the price-cost margin will increase by $0.824 \%$ following a $1 \%$ rise in industrial concentration. Additionally, the HHI coefficient of 0.091 shows that the price-cost margin will increase by 0.091 units for every 1-unit (1000) increase in HHI. Therefore, results show that firms in the food and beverages sector benefit from the oligopolistic market structure. This result is also supported by the data, given that every year, on average, the industry experienced about $18.1 \%$ of price-cost margin from 1995-2006 (see Table 1). The results presented here also support the findings of other studies, such as Shirazi (1974), Prince and Turik (1992), Kalirajan (1993), Go, Kamerschen, and Delorme (1999), and Delorme, Kamerschen, Klein, and Voeks (2002), which found a positive impact of industrial concentration on the price-cost margin.

Furthermore, based on the estimated fixed effects of both models with CR4 and HHI, it is observed that without any influences of the industrial concentration and other variables in the model (ceteris paribus), the subsectors of the food and beverages sector have a heterogeneous price-cost margin. ${ }^{13}$ It is also found that the subsectors that are among the least concentrated have a high price-cost margin, indicating that for these subsectors, the degree of concentration is not a very good predictor of PCM. Instead, the high price-cost margin is captured in the model by the fixed-effects, ${ }^{14}$ which is not surprising because fixed effects parameters do not take into account some unobserved heterogeneities, such as different characteristics of the industry and scale effect.

\footnotetext{
${ }^{13}$ In the CR4 model, the lowest and the highest fixed effects parameters are -0.248 and 0.333 , respectively. Almost similar to the CR4 model, in the HHI model, the lowest and the highest fixed effects parameters are -0.253 and 0.200 , respectively.

${ }^{14}$ Based on the parameters of the fixed effects of the model with CR4, some subsectors, such as 15492 (ice cubes and other ice products), 15421 (granulated sugar), 15141 (crude cooking oil), 15540 (soft drinks), and 15496 (crackers and other chips), have the highest price-cost margin in the period of estimation. However, some subsectors, such as 15329 (other starch nec), 15321 (wheat flour), 15530 (beer), 15134 (dried food, vegetables), and 15312 (other grain milling), have the lowest price-cost margin in the period of estimation.

Also, based on the parameters of the fixed effects of the model with HHI, some subsectors, such as 15421 (granulated sugar), 15510 (liquors), 15540 (soft drinks), 15139 (other fruit and vegetables), and 15141 (crude cooking oil), have the highest price-cost margin in the period of estimation. However, some subsectors, such as 15329 (other starch nec), 15134 (dried food, vegetables), 15125 (processed fish), 15321 (wheat flour), and 15423 (other sugars), have the lowest price-cost margin in the period of estimation.
} 
The parameter associated with the trend suggests a positive movement of the price-cost margin during the period. The trend variable coefficient shows that the price-cost margin increases by 0.036 and 0.049 each year for the CR4 and HHI models, respectively.

To examine the effect of the competition law on the price-cost margin, the first order derivatives are calculated for the CR4 and HHI models. We obtain: ${ }^{15}$

$$
\begin{aligned}
& \frac{\partial P C M}{\partial L a w}=0.373-0.342 \times C R 4-0.031 \times \text { trend } \\
& \frac{\partial P C M}{\partial L a w}=0.339-0.064 \times H H I-0.049 \times \text { trend }
\end{aligned}
$$

The averages for CR4 and HHI are 0.633 and 2,266, respectively, and the average trend is 5.5. The net effects of the law on PCM are calculated as -0.014 and -0.075 for the CR4 and HHI models, respectively. The results regarding the Law variable suggest that the Competition law has affected price-cost margin in various ways. First, the parameters associated with the interaction term of Law and the concentration ratios (CR4 and HHI) show that the policy has had a more negative effect on the price cost margins of subsectors that were characterized by higher concentration ratios, which implies that the policy has been targeted more toward sectors with a high price cost margin. Second, the parameters of the interaction terms of Law and trend (-0.031 and -0.049) (almost) offset the positive single trend term, which suggests that the policy was successful in stopping the upward trend in price cost margins before 1999.

Regarding the results on the relationship between the law establishment and the price-cost margin, a number of comments are in order. First, the competition policy may not have been applied effectively to reduce market power. McCloughan et al. (2007) argues that only an effective competition policy would decrease the price-cost margin. Additionally, Pangestu et al. (2002) found ambiguities that are still subject to interpretation in the Indonesian competition law, which may make the investigation and the law enforcement on anti-competitive behavior ineffective. Second, the political stability and improved economic environment in 2004-2006 may have resulted in higher profits, thereby confounding the effects of the competition law. Better stability and economic environment during 2004-2006 may come as a result of successful parliamentary and presidential elections in 2004. Indeed, the data in Table 2 show that the price-

\footnotetext{
${ }^{15}$ We slightly abuse notation here. Although we use the partial derivative sign, we evaluate the effect of the competition law as the dummy variable changes from zero to one.
} 
cost margin increased steadily from 2004 until 2006. Third, the law establishment may induce firms to innovate and produce differentiated products that may sustain higher prices (Looi Kee and Hoekman, 2003), which may result in higher price cost margins. Indeed, since 1999, the variety of products has been significantly increasing in Indonesia. Fourth, the increase of the industrial concentration for subsectors with low industrial concentration in the initial year may cause the increase of the price-cost margin, on average (as predicted by the model of absolute convergence in Equation (4)). This finding is in line with the finding that the competition law affected the subsectors with high industrial concentration ratios more seriously. Finally, although there are some factors that may cause the elevation of the price-cost margin, this result may give a further recommendation for an improvement in the competition law in the industry.

\section{Conclusions}

This paper has investigated the trend and convergence of industrial concentration in the Indonesian food and beverages sector. Moreover, it has analyzed the relationship between the industrial concentration and the price-cost margin. This paper contributes to the literature by applying the concept of convergence to the analysis of the trend in industrial concentration. Furthermore, this paper contributes an analysis of the relationship between market structure and industrial performance in the food and beverages sector in Indonesia.

The results show that the industrial concentration of the subsectors in the food and beverages sector tend to be slightly lower in the long run, but the subsectors of the industry still have a high industrial concentration (tight oligopoly structure) in the period covered by the data. In addition, results show that the industrial concentration converges to the same value for all subsectors. Finally, as expected, the industrial concentration is found to have a positive effect on the pricecost margin.

The competition law has been relatively more successful in reducing the price-cost margin in subsectors that are characterized by a relatively high industrial concentration. Furthermore, the law has almost stopped the upward trend in price-cost margins that existed before the implementation of the law. Nevertheless, the price-cost margin is still higher after the competition law establishment than before, which suggests that a further improvement of the competition law is warranted. 
The results of this paper demonstrate that higher concentration in a subsector leads to a higher price-cost margin. One way to lower anti-competitive behavior is to eliminate barriers to entry, which effectively lowers concentration. However, the results presented here suggest that the effect of the competition law on the price-cost margin is through the concentration. More precisely, the competition law lowers the effect of concentration on the price-cost margin by breaking cartels.

\section{References}

Bain, J. S. (1956) Barriers to New Competition, Harvard University Press, Cambridge, MA.

Bain, J.S. (1951) Relation of profit rate to industry concentration : American manufacturing, 1936-1940, Quarterly Journal of Economics, 65, pp. 293-325

Barro, Robert J. and Sala-I-Martin, Xavier (1992) Convergence, Journal of Political Economy, 100, pp. 223-252

Besanko D., Dranove D, Shanley M, Schaefer S. (2004) Economics of strategy 3rd Ed. New York (NY): Wiley

Bird, Kelly (1999) Concentration in Indonesia manufacturing 1975-93, Bulletin of Indonesian Economic Studies, 35, pp. 43-73

Brozen, Y., (1982) Concentration, Mergers, and Public Policy, Macmillan, New York.

Bureau of Central Statistics Republic of Indonesia (2008), Survey on Industrial Manufacturing 1995-2006, BPS

Carlton, Dennis W. and Perlof, Jeffrey M. (2005) Modern Industrial Organization, Fourth Edition, The Addison-Wesley Series in Economics.

Castilla, Carolina (2008) Heteroscedasticity in fixed-effects one-way error components models : evaluating the performance of standard tests, SSRN-id1351063

Clarke, Roger and Davies, Stephen W. (1982) Market structure and price-cost margins, Economica, New Series, 49(195), pp. 277-287

Collins, Norman R. and Preston, Lee E. (1969) Concentration and price-cost margin in food manufacturing industries, The Journal of Industrial Economics, 14(3), pp. 226-242

Cowling, Keith and Waterson, Michael (1976) Price-cost margin and market structure, Economica, 43, pp. 267-274 
Delorme Jr., Charles D., Kamerschen, David R., Klein, Peter G. and Voeks, Lisa Ford (2002) Structure, conduct, and performance : a simultaneous equations approach, Applied Economics, 34, pp. 2135-2141

Dickson, Vaughan (2005) Price-cost margins, prices, and concentration in US manufacturing: a panel study, Applied Economics Letters, 12(2), pp. 79-83

Domowitz, Ian, Hubbard, R. Glenn and Petersen, Bruce C. (1986) Business cycles and the relationship between concentration and price-cost margins, The RAND Journal of Economics, 17(1), pp. 1-17

Domowitz, Ian, Hubbard, R. Glenn and Petersen, Bruce C. (1988) Market structure and cyclical fluctuations in U.S. Manufacturing, The Review of Economics and Statistics, 70(1), pp.55-66

Domowitz, Ian, Hubbard, R. Glenn, and Petersen, Bruce C. (1993) Market structure and cyclical fluctuations in U.S. manufacturing : Reply, The Review of Economics and Statistics, 75(4), pp. 734-735

Fischer, Thorsten, and Kamerschen, David R. (2003a) Measuring competition in the U.S. airline industry using the Rosse-Panzar test and cross-sectional regression analysis, Journal of Applied Economics, VI(1), pp. 73-93

Fischer, Thorsten, and Kamerschen, David R. (2003b) Price-cost margins in the US airline industry using a conjectural variation approach, Journal of Transport Economics and Policy, 37(2), pp. 227-259

Gan, W. B. (1978) The relationship between market concentration and profitability in Malaysian manufacturing industries, April, Malayan Economic Review

Gan Wee Beng and Yen, Tham Siew (1977) Market structure and price-cost margins in Malaysian manufacturing industries, The Developing Economies, 15(3), pp. 280-292

Ghosal, Vivex (1989) Market structures, price-cost margins, and unionism : an empirical note, Economics Letters, 29, pp. 179-182

Go, Gerald L., Kamerschen, David R. and Delorme, Charles D. (1999) Market structure and price-cost margin in Phillipine manufacturing industries, Applied Economics, 31, pp.857-864

Gujarati, Damodar (2004) Basic Econometrics, $4^{\text {th }}$ edition, The McGraw-Hill Companies

Gupta, Vinod K. (1983) A simultaneous determination of structure, conduct, and performance in Canadian manufacturing, Oxford Economic Paper, 35(2), pp. 281-301 
Hill, H. (1987) Concentration in Indonesian manufacturing, Bulletin of Indonesian Economic Studies, 23(2), pp. 71-100

Im K.S., M.H. et, Pesaran and Y., Shin (2003) Testing for unit roots in heterogeneous panels,, Journal of Econometrics, 115 (1) , pp. 53-74

Jacquemin, Alexis, Gellinck, Elisabeth de and Huveneers, Christian (1980) Concentration and profitability in a small open economy, The Journal of Industrial Economics, 29(2), pp. $131-144$

Kalirajan, K.P. (1993) On the simultaneity between market concentration and profitability : the case of a small-open developing country, International Economic Journal, 7(1), pp. 3148

Kamerschen, David R., and Jae-Hee Park (1993a) An alternative approach to market structure and the mark-up ratio, Applied Economics, 25, pp. 111-124

Kamerschen, David R., and Jae-Hee Park (1993b) Market structure and cyclical fluctuations in U.S. manufacturing : Comment, The Review of Economics and Statistics, 75(4), pp. 732734

Kamerschen, David R. (1994) Testing for antitrust market definition under the Federal Government Guidelines, Journal of Legal Economics, 4(1), pp. 1-10

Kamerschen, David R., Klein, Peter G., and Porter, David V. (2005) Market structure in the US electricity industry : a long term perspective, Energy Economics, 27, pp. 731-751

Khemani, R.S., (1980) Analysis of post-war changes in industrial concentration in Canadian manufacturing 1947-1972, Department of Consumer and Corporate Affairs, Canada

Konings, J., Van Cayseele, P. and Warzynski, F. (2001) The dynamics of industrial mark-ups in two small open economies: does national competition policy matter, International Journal of Industrial Organization, 19, pp.841-859.

Levenstein, Margaret C. (2003) Review of george symeonidis, the effects of competition: cartel policy and the evolution of strategy and structure in British industry, EH.Net Economic History Services, July 9

Levin, A., Lin. C.-F. and Chu, C-S (2002) Unit root tests in panel data: asymptotic and finite sample properties, Journal of Econometrics,108, pp.1-24

Liebenberg, Andre P. and Kamerschen, David R. (2008) Structure, conduct, and performance analysis of the south African auto insurance market: 1980-2000, South African Journal of Economics, 76(2), pp. 228-238 
Looi Kee, Hiau, and Hoekman, Bernard (2006) Imports, entry, and competition law as market disciplines, European Economic Review, 51(4), pp.831-858

McCloughan, Patrick, Lyons, Sean and Batt, William (2007) The effectiveness of competition policy and the price-cost margin: evidence from panel data", Working Paper No. 209, ESRI

Mueller, W.F., and Hamm, L.G. (1974) Trend in industrial concentration 1947 to 1970, The Review of Economic and Statistics, LIV(4)

Pangestu, Mari, Aswicahyono, Haryo, Anas, Titak and Ardyanto, Dionisius (2002) The evaluation of competition policy in Indonesia, Review of Industrial Organization, 21, pp. 205-224

Pepall, Richards and Norman (2008) Industrial Organization, 4th Edn (eds), South Western

Quantitative Micro Software (2007) Eviews 6 User Guide II, Quantitative Micro Software, LLC

Sala-I-Martin, Xavier (1996) The classical approach to convergence analysis, The Economic Journal, 106(437), pp. 1019-36

Saving, Thomas R. (1970) Concentration ratios and the degree of monopoly, International Economic Review, 11(1), pp. 139-146

Shepherd, W. (1999) The Economics of Industrial Organization, Waveland Press, Illinois

Shirazi, Javad Khalilzadeh (1974) Market structure and price-cost margin in United Kingdom manufacturing industries, The Review of Economics and Statistics, 56(1), pp. 67-76

Sorensen, Peter Birch and Whitta-Jacobsen, Hans Jorgen (2005) Introducing Advanced Macroeconomics : Growth and Business Cycles, the McGraw-Hill 